\title{
暗調応に及ぼすアスコルビン酸, ビタミンB類および牛乳の影響 Effect of Ascorbi Acid, Vitamin B and Milk on the Dark Adaptation
}

\author{
（昭 和 37 年 2 月 22 日受理）
}

\author{
小柳達 男鹰 觜テ ル* \\ (Tatsuo Koyanagi) (Teru Takanohashi)
}

\begin{abstract}
Although the validity of the dark adaptation test for showing mild degree of a vitamin A deficiency is now generally acknowledged, there are many contradictory reports concerning the effect of vitamin $A$ on the dark adaptation. The effect of vitamins other than $A$ on it is yet uncertain. The results of the present experiment indicate that most of the impaired dark adaptation for children can be cured by the supplement of ascorbic acid, vitamin B and milk together with vitamin A. Discrepancies among reports on the effect of vitamin $A$ on the improvement of dark adaptation in the past may be explained by the facts that the diets of their subjects had been deficient in some nutrients other than vitamin A.
\end{abstract}

ヒタミンA（A）が不足してくると暗調応，すなわち 暗所で敞光を認める能力が減退してくるととは一般に知 られている。Harris 1）らは英国の児童の暗調応を測定 して，Aに不足している食物を摂取している児童は一般 に暗調応が不良であるのに対し，栄養のよい児童は暗調 㐫の覀いととはまれであると報告している。

Josephs ら2) は血中のAの含量と暗調応と比例すると とを報告し，英国医学研究委員会は血中の A含量か 50 .I.U 以下になると暗調応が德くなると述べている3)。し かし，一方に招いて Hecht ら4) は暗調応能力の低下は A欠乏食ですぐに起きるがこれにAを多量に与えても恢 復に 6 １2週を要するととがあり，どうしてもな打らぬ 者むあるといっている。-Dowling ら5) むある人々はA を飲んで数時間で不良な暗調応が完全に饭復するのに， 人によってはAの服用で少しはよくなるが，それ以上服 用を数力月続けても完全にはならないのを認めた。

A以外のピタ:ンと暗調応との関係に関しては, Stewart 6), Waldら 7) はアスコルビン酸 (C) が重要であ ろうといったが Yudkin8) は6 6 人の暗調応の悪い人々 そついてそのCの欠乏状態ではないととからはっきりと 否定した。ニコチン酸は細谷 9)か3 3 人の暗調応の悪い 患者に与えた結果 $5 〜 24$ 時間の間に 1 人には効き， 1 人 は僅加效いたと報告している。しかし被験者Aの状的 てついては調べていない。
Kimbleら 10) は、暗調芯が悪く血液中のA含量も低い 患者にAを多量に与えたとてろ，何らの効果がなかった がリボフラビン $\left(\mathrm{B}_{2}\right)$ を $\mathrm{A}$ と一緒に与えたととろがはじ めて正常になった。ある贯者は $\mathrm{A}$ と $\mathrm{B}_{2}$ とだけでは効果 がなかったが A と C とを与えると著しく具合がよくなっ たと報告している。乙の報告について Biknell らは11) $\mathrm{B}_{2}$ は $\mathrm{A}$ の吸収, あるいは移動に必要なように思われる と批判している。

さて, われわれ 12) は岩手県で畑作地带, 水田地带, 扰よび盛岡市の学童各20人の栄崣調査を行なった際に暗 調応を測定した結果それぞれ7.7，4.0 打よび 1.2 (光度 計のレンズのしほり $\mathrm{mm}$ ) という大差があり，ひえを常 食とする畑作地带がきわめて不良であり，さらに烟作地 带, あるいは水田地带では肝油を飲用している者む, そ れぞれ6.9，あるいは $3.7(\mathrm{~mm})$ にしか改善されていな いととを認めた。すなわち，乙の成績は隌調応が肝油飲 用のみによっては完全に改善できぬ場合があること，換 言すれば暗調応には肝油以外の栄養素の影響があるとと を示すのであろうと考えられた。

本報告は学童の暗調応に対してビタミンの服用拒よび 牛乳の飲用が如何なる影響を及ほすかを知るために行な った試験について述へたものである。

$$
\text { 方法 }
$$


暗調応の测定は短時間に多数の人について測定するた め Harris 1) らの方法を多少改変して行なった。

壁に張った白紙 $76 \mathrm{~cm} \times 109 \mathrm{~cm}$ から $1 \mathrm{~m}$ 觹れたところ に被験者を立たせ， 5 分間この中央を疑視させる。この 紙は被験者の頭上にある 100ワットの電灯で照らしてい るものである。このようにして網膜を漂白したのち完全 な暗室に静座させ正確に10分後に Birch Hirschfeld の 光度計で測定した。被験者は光度計より $30 \mathrm{~cm}$ のとと ろに眼があるように座す。光度計についたレンズのしぼ りを除々に開き，内部から出る微光をはじめて缌めたと きのしほりの直径を読みとるのである。その読みが 2 $3 \mathrm{~mm}$ を正常, $4 \sim 5 \mathrm{~mm}$ をほとんど正常, $6 \mathrm{~mm}$ 以上 を不良とした。栄養状態のよい正常と考えられる人につ いて正常值を確加めて拓くとよい。測定にあたってはし ほりを開いて扣いてから見えなくなるときの読みもとっ てその中間の值を記録した。

\section{結果}

\section{A, $\mathrm{B}_{2}$, C打よび牛乳の順で添加した場合}

岩手県下閉伊郡宮守村塚沢小学校て12月23日上り試験 然行なった。被験者は 3 年生 24 名で試験結果は第 1 表の 如くである。14日間, 続いて24日間 1 日 1 人肝油ドロッ プ (3,000 I. U.含有) でAを与えたのちに抳てても，暗 調応はそれぞれ6.7，6.2mmに止った。肝油ドロップと とむに $2 \mathrm{mgD} \mathrm{B}_{2}$ を含む乳糖の錠剂 ( 1 錠の重量 $0.2 \mathrm{~g}$ ) を 1 週間与えると $5.8 \mathrm{~mm}$ になり，100mg のCを含む乳

第1表 $\mathrm{A} ， \mathrm{~B}_{2} ， \mathrm{C}$ 打よび牛乳の順に与えた場合 の暗調応の変化

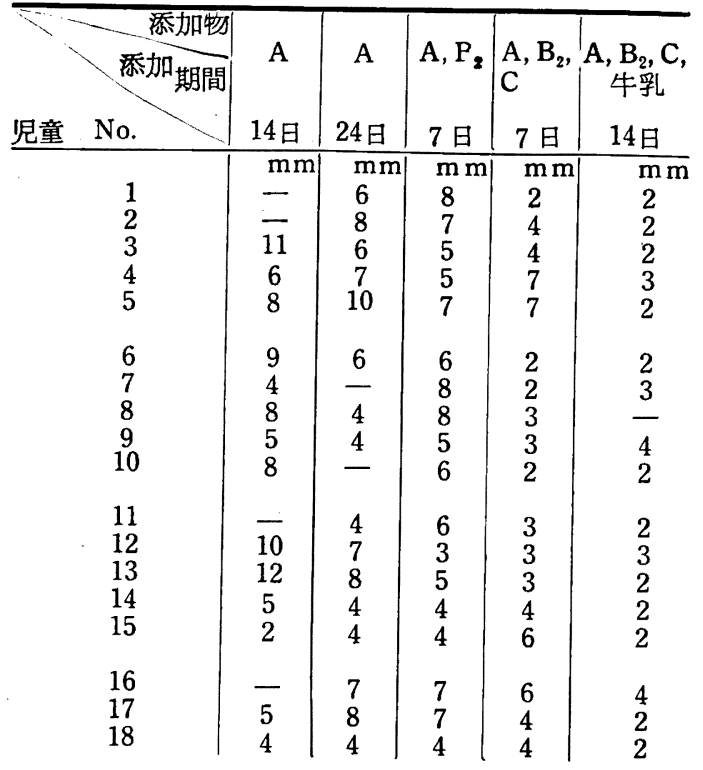

\begin{tabular}{|c|c|c|c|c|c|c|}
\hline & & $\underline{7}$ & $\begin{array}{l}8 \\
4\end{array}$ & $\begin{array}{l}4 \\
7\end{array}$ & $\frac{2}{5}$. & $\begin{array}{l}2 \\
3\end{array}$ \\
\hline & & $\begin{array}{l}\frac{4}{6} \\
6\end{array}$ & $\begin{array}{l}8 \\
8 \\
6 \\
6\end{array}$ & $\begin{array}{l}4 \\
5 \\
6 \\
8\end{array}$ & $\begin{array}{l}3 \\
2 \\
-\end{array}$ & $\begin{array}{l}2 \\
4 \\
2 \\
2\end{array}$ \\
\hline & 均 & $\begin{array}{c}6.7 \pm \\
2.66 *\end{array}$ & $\begin{array}{r}6.2 \pm \\
1.66\end{array}$ & $\begin{array}{r}5.8 \pm \\
1.53\end{array}$ & $\begin{array}{c}3.5 \pm \\
1.62\end{array}$ & $\begin{array}{r}2.4 \pm \\
0.73\end{array}$ \\
\hline
\end{tabular}

*: 平均士標準偏差

糖の錠片を肝油， B : とともに 1 週間与えると $3.5 \mathrm{~mm}$ 亿 なり、これらのビタミンとともに $360 \mathrm{ml}$ の牛乳を 2 週間 続けて与えると $2.4 \mathrm{~mm}$ という正常值になった。

この各期間中無添加 10 人の児童の暗調芯は 7.2,6.0, 8.0，7.3，6.2mmで不良のままであった。

2. C, B, A 拒よび牛乳の順に与えた場合

前試験でCが特に暗調応改善に効果があったのてCを 先に添加してみた。試験は 4 月22日より, 盛岡市上田小 学校 1 年生 20 名について行なった。その結果は第 2 表の 如くでのの 2 日間の添加では目だった効果がないがで れとともに $2 \mathrm{mg}$ のサイアミン塩酸塭 $\left(\mathrm{B}_{1}\right), 2 \mathrm{mg}$ の $\mathrm{B}_{2}, 10 \mathrm{mg}$ のパントテン酸カルシウム, $20 \mathrm{mg}$ のニコチ ン酸を一つの鎵剤にして 8 日間加えると $3.9 \mathrm{~mm}$ 亿なり， これらに肝油を加えて飲用するととを 7 日間行なった絬

第 2 表 C, B 群, A 打よび特乳の順に与えた場合 の暗調応の変化

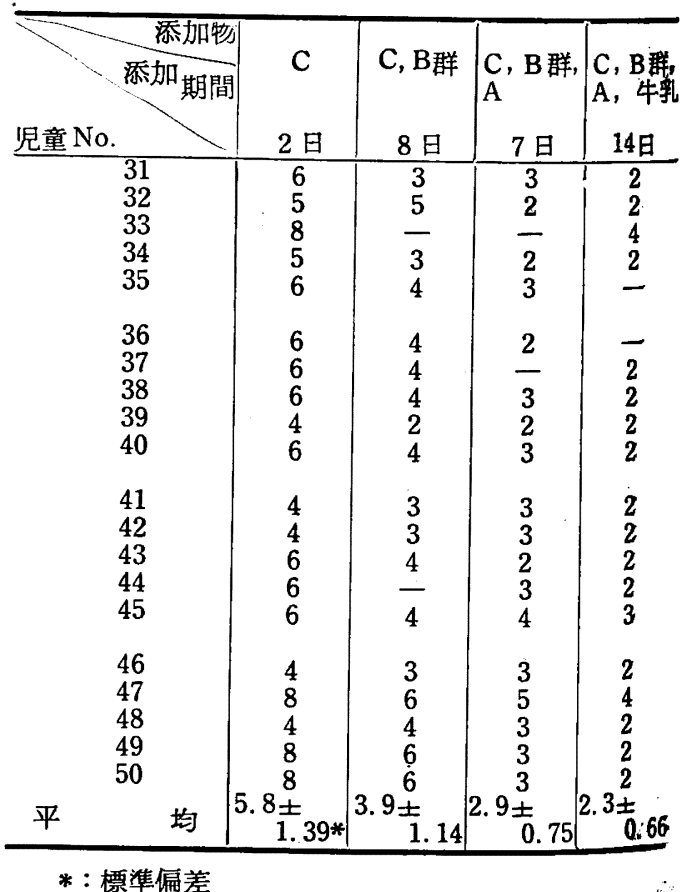

果 $2.9 \mathrm{~mm}$ になった。さらに牛釈 $360 \mathrm{ml}$ をこれらと共に 与えると 2 週間 $2.3 \mathrm{~mm}$ とさらに改善された。 
3. A, C, B

7月 1 日より盛岡市東大田小学校学年児童について試 㻌した。この学校は肝油の飲用をすでに行なっていた。

第 2 武験ではCだけ与えたのでは効果がなかったの て，Aの存在でCを与えると効果を示すか否かを確める ために試睮した。その結果は第 3 表に示した。

第3表 $\mathrm{A}, \mathrm{C}, \mathrm{B}_{2}, \mathrm{~B}$ 群扰よび牛乳の順に与え た場合の暗調応の変化

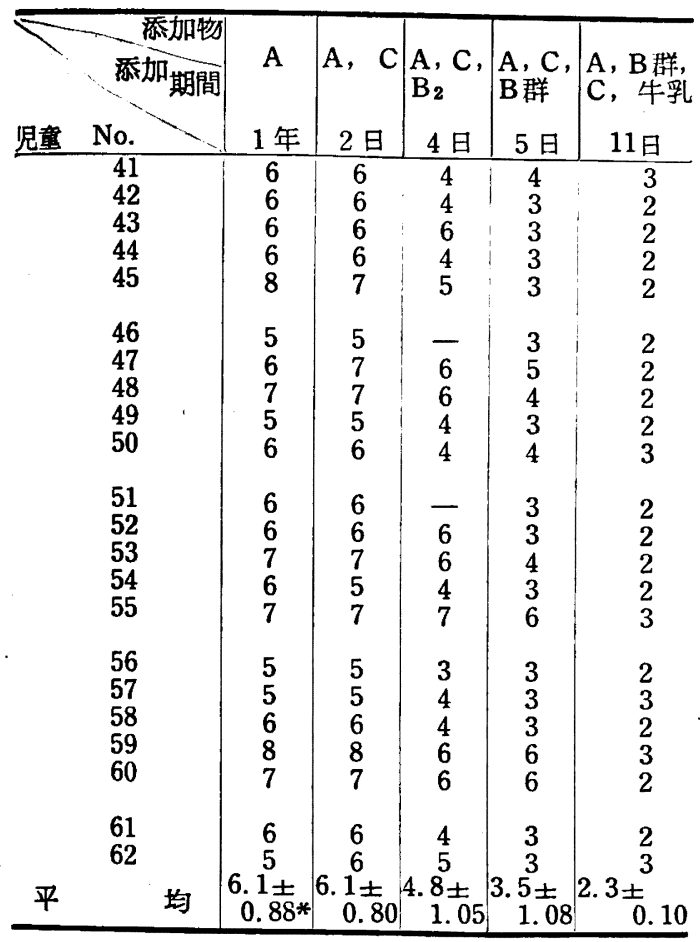

* : 標準偏差

その結果はAが与えられていても Cの添加は効果がほ とんどみられす， $\mathrm{B}_{\mathbf{2}}$ が同時に添加されるとめさましい 改善を示した。 $B_{1}$, パントテン酸, ニコチン酸がてれ に加わるとさらによくなり，最後に牛乳を飲用させると 完全に正常になった。

\section{考察}

\&上の試験によって不良な暗調応は $\mathrm{A}$ のほか $\mathrm{B} ， \mathrm{C}$ 打 よび牛乳を与えると正常になるととを知った。Aが暗調 沁の改善に対する効果について従来一致した成績がなか ったのは, 被験者が A以外のビタミンあるいは牛乳中の 成分に不足していたためであろう。Dowling ら5）はA 久乏による夜盲症の進行について二即階あるととを認め ている。最初にAの欠乏により網膜にある rhodopsin の诚少のために扔てる微光を琶める能力の減退が起と
り，次に opsin が減少して桿う構造変化が起きるという のである。Aはこのように rhodopsin の活性分子として 役だつしB拓よびCは損なわれた桿つ構造上の改善扔よ び網膜の酸化反応に関係するのであろう。

な扔都市抢よび農村の学童が程度の差はあっても暗調 応が正常でないむのが大部分であるということ，打よび ビタミン，牛乳の添加あるいは飲用によりこれが正常に なるというととはこれらの不足が広くひろがっていると とを示し，国民栄養上留意すべきととと思われる。

\section{要 約}

暗調応テストはAの欠乏度判定する方法として応用 されたが，肝油の飲用によっても完全に正常にならぬ場 合があった。本研究は暗調応の改善に及ぼす A以外の栄 養素の影響を試験したものである。

その結果，暗調忘にはAのみでなくビタミン B 類, 扔 よびCが関与してれらを A と同時に服用させると著しい 改善が見られ，さらに牛乳を同時に飲用させると正常に なることを認めた。

本研究に使用した肝油ドロップ扰よび水溶性ビタミン 錠剂は，それぞれ河合製薬株式会社，打よび東重栄養化 学株式会社の寄䁌によるものである。記して謝意を表わ す。な技実験は, 稲垣聖子, 橋元浩子, 藤原有子, 成田 訓子の協力によって行なった。

本研究の大要は第 127 回ビタミンB委貴会 (要旨, ピ タミン，23，324，(1961）に扔いて発表した。

\section{交献}

1) Harris, L. J. and Abbasy, M. A, ; Lancet, 1299 (1939)

2 ) Josephs, H. W. et al. ; Bull. Johns Hotkins Hospital. 68, 375 (1941)

3 ) Med. Res. Coun. Spec. Rep. Ser., No. 264 (1949)

4) Hecht, S. and Mandelbaum, J. ; Am. J. Physiol., 130, 651 (1940)

5 ) Dowling, J. E. and Wald, G. ; Proc. Natl. Acad. Sci., 46, 587 (1960)

6) Stewart, C. P. ; J. Physiol., 96, 28 (1939)

7 ) Wald, G and Steven, D. ; Am. J. Physiol., 126, 648 (1939)

8 ) Yudkin, S. ; Lancet, ii, 787 (1941)

9) Hosoya, Y., Fang, H. S. and Peng, M. T. ; Tchoku J. Exp. Med., 53, 103 (1950)

10) Kimble, M. S. and Gordon, E. S. ; J. Biol. Chem., 128, 1ii (1939)

11) Bicknell. F and Prescott, F. ; Vitamine in Medicine, Heinemann, Medical Books, Ltd, London. (1952)

12) Koyaragi, T. and Takanol ashi, T. : Nature, 192, 457 (1961)

(菓北大学農学部栄意学研究室)

* (岩手大学学芸学部家政科教室) 